\title{
MENINGKATKAN HASIL BELAJAR SISWA PADA MATERI PERKEMBANGAN TEKNOLOGI PRODUKSI MELALUI MODEL GROUP INVESTIGATIONDI KELAS IV SDN 6 BULANGO SELATAN
}

\author{
Yane Hardiyanti Mahmud \\ Program Studi Guru Sekolah Dasar, Universitas Muhammadiyah Gorontalo \\ e-mail: yanehardiyantimahmud@umgo.ac.id
}

\begin{abstract}
This journal is about improving student's Learning Outcomes in production Technology development through Group Investigation model In Grade IV of SDN 6 Bulango Selatan, Gorontalo Regency. The objective of this study is to improve students' learning outcomes in Production Technology Development through Group Investigation model in Grade IV of SDN 6 Bulango Selatan. The researcher used classroom action research which was conducted in two cycles (CAR). The technique of collecting data is observation, tests, and documentation. From the preliminary observations, the percentage of students' completeness is $32 \%$ or 8 of 25 students in Grade IV of SDN 6 Bulango Selatan while the average value is 47.6. In cycle I, the level of students' completeness percentage increased to $48 \%$ or 12 of 25 students. In the cycle 2, the percentage of students' completeness reached $84 \%$ or 21 of 25 students in Grade IV SDN 6 Bulango Selatan.
\end{abstract}

Keywords: Students' Learning; Technology Development

\begin{abstract}
Abstrak
Telah dilakukan penelitian mengenai meningkatkan hasil belajar siswa pada materi perkembangan teknologi produksi melalui model Group Investigation di kelas IV SDN 6 Bulango Selatan Kabupaten Gorontalo. Tujuan penelitian ini adalah untuk meningkatkan hasil belajar siswa pada materi perkembangan teknologi produksi melalui model Group Investigation di kelas IV SDN 6 Bulango Selatan. Metode penelitian tindakan kelas yang dilaksanakan dalam dua siklus (PTK). Teknik pengumpulan data menggunakan observasi, tes, dan dokumentasi. Hasil penelitian menunjukan bahwa; Dari hasil observasi awal tingkat presentase ketuntasan siswa
\end{abstract}


hanya sebesar 32\% atau 8 orang dari 25 siswa yang ada dikelas IV SDN 6 Bulango Selatan. Sedangkan nilai rata-rata kelas sebesar 47,6. Pada siklus I terlihat tingkat presentase ketuntasan siswa meningkat menjadi $48 \%$ atau 12 orang dari 25 siswa. Pada siklus II terjadi peningkatan presentase ketuntasan siswa yaitu mencapai $84 \%$ atau 21 orang dari 25 siswa jumlah siswa yang ada dikelas IV SDN 6 Bulango Selatan.

Kata Kunci: Hasil Belajar; Perkembangan Tekhnology

\section{PENDAHULUAN}

Bagian ini berisi latar belakang munculnya permasalahan yang ditulis dalam sebuah artikel. Untuk Terkait permasalahan hasil belajar pada mata pelajaran IPS di SDN 6 Bulango Selatan maka penulis berusaha memberikan alternatif pemecahan masalah melalui penerapan salah satu model pembelajaran dari pendekatan pembelajaran cooperative learning yaitu model belajar Group Investigation (investigasi kelompok) untuk meningkatkan hasil belajar siswa dalam pembelajaran IPS. Pada dasarnya setiap model pembelajaran yang digunakan guru dalam menyajikan materi mengisyaratkan adanya tugas, tujuan, dan nilai. Menurut Rusman (2011 : 202) pembelajaran kooperatif (Cooveratif Learning) merupakan bentuk pembelajaran dengan cara siswa belajar dan bekerja dalam kelompok-kelompok kecil secara kolaboratif yang anggotanya terdiri dari empat sampai enam orang dengan stuktur kelompok yang heterogen Penerapan model Group Investigation ini merupakan refleksi dari pentingnya pengelolaan pembelajaran yang inovatif dan efektif. Pada dasarnya setiap model pembelajaran yang digunakan guru dalam menyajikan materi mengisyaratkan adanya tugas, tujuan, dan nilai. Group investigation adalah strategi belajar kooperatif yeng menempatkan siswa ke dalam kelompok untuk melakukan investigasi terhadap suatu topic dikembangkan oleh Sharan dalam (Maufur, 2009 :128) model yang dianggap paling sulit untuk dilaksanakan dalam pembelajaran kooperatif, karena model ini melibatkan siswa sejak perencanaan, baik dalam menentukan topik maupun cara untuk mempelajarinya melalui investigasi 
(penyelidikan). Hasil belajar siswa Provinsi Gorontalo.

merupakan salah satu faktor penting Variabel Penelitian

untuk mengukur keberhasilan - Variabel input

seseorang dalam belajar. Menurut a. Siswa kelas IV SDN 6 Bulango

Suprijono (2009 : 5) hasil belajar adalah Selatan, Kecamatan Bulango Selatan, pola - pola perebutan, nilai-nilai, pengertian - pengertian, sikap - sikap apresiasi dan keratmpilan Dalam penelitian ini, peneliti menggunakan pendekatan kontekstual dengan model pembelajaran cooperative learning tipe group investigation. Berdasarkan permasalahan di atas, penulis tertarik untuk mengadakan penelitian mengenai "Meningkatkan Hasil Belajar Siswa Pada Materi Perkembangan Teknologi Produksi Melalui Model Group Investigation di Kelas SDN 6 Bulango Selatan" Kabupaten Bone Bolango.

b. Guru mengadakan pembelajaran di kelas IV sesuai dengan Rencana Pelaksanaan Pembelajaran ( RPP ).

c. Bahan ajar yaitu menyangkut dengan materi yang akan diberikan.

d. Sumber belajar yaitu Buku IImu Pengetahuan Sosial kelas IV.

e. Prosedur penelitian dengan penggunakan tes dan evaluasi agar mengetahui hasil belajar siswa.

f. Lingkungan belajar SDN 6 Bulango Selatan sebagai lingkungan dalam proses pembelajaran

\section{- Variabel Proses}

\section{METODE PENELITIAN}

a. Mengidentifikasi topik dan

\section{Latar Penelitian dan Karakterristik} mengatur murid kedalam beberapa

\section{Subjek Penelitian}

SDN 6 Bulango Selatan
merupakan salah satu sekolah yang ada di wilayah Kecamatan Bulango Selatan. SDN 6 Bulango Timur terletak di Jalan. Irigasi Lomaya Tapa Desa Mekar jaya yang merupakan pemekaran dari Desa Huntu Utara, Kecamatan Bulango Selatan, Kabupaten Bone Bolango, kelompok kecil.

b. Merencanakan tugas yang akan dipelajari.

c. Melaksanakan investigasi.

d. Menyiapkan laporan akhir.

e. Mempresentasikan laporan akhir.

f. Evaluasi.

g. Penutup

\section{- Variabel Output}

Yang menjadi variabel output, yakni 
meningkatkan hasil belajar siswa melalui group investigation dalam perkembangan teknologi produksi di SDN 6 Bulango Selatan, Kecamatan Bulango Selatan, Kabupaten Bone Bolango Selatan

\section{a. Prosedur Penelitian}

- Pelaksanaan Penelitian Tindakan Kelas (PTK) menggunakan prosedur model spiral menurut kemmis dan taggart dalam (Wiriatmadja 2009:66 -67) terdiri atas empat langkah yaitu : (1) persiapan. (2) pelaksanaan. (3) pemantauan dan evaluasi. (4) analisis dan refleksi. - Tehnik Analisis Data. Data yang diperoleh dari hasil pemantauan dan evaluasi akan dianalisis baik secara kuantitatif maupun secara kualitatif dan hasilnya untuk merefleksi diri dan seluruh proses kegiatan. Dalam hal ini akan diketahui kekuatan dan kelemahankelemahan yang terjadi pada proses yang telah berlangsung kemudian ditindak-lanjuti pada kegiatan berikutnya serta menjadi bahan untuk menyusun laporan penelitian. 1). Pengelolaan pembelajaran yang dinilai melalui lembar pengamatan memperoleh skor minimal $70 \%$ mencapai kategori yang baik. 2).
Standar ketuntasan minimal hasil belajar siswa secara klasikal $80 \%$ dari jumlah siswa memperoleh jumlah skor minimal 70 keatas. Untuk mengetahui hal tersebut diatas, maka digunakan rumus sebagai berikut. Nilai $=$ Skor perole han siswa Skor ideal $\times 100$ Ketuntasan Belajar $=$ Jumla $h$ siswa yang memperole $h$ nilai $\geq 70$ Jumla $h$ siswa keseluru han $\times 100 \%$ Dari hasil pengamatan ketuntasan belajar siswa dikelompokkan sebagai berikut $70 \%$ $100 \%=$ Tuntas $0 \%-69 \%=$ Tidak Tuntas.

\section{HASIL DAN PEMBAHASAN}

a. Hasil Pelaksanaan Pembelajaran Siklus I

- Tahap Persiapan. Setelah dilakukan observasi awal terhadap hasil belajar siswa dalam mata pelajaran IPS, maka kegiatan selanjutnya adalah menyiapkan beberapa hal yang diperlukan pada saat pelaksanaan tindakan siklus I, yaitu 1). Rencana Pelaksanaan Pembelajaran, 2). Lembar Pengamatan aktivitas guru dan siswa, dan 3). Tes. - Tahap Pelaksanaan. Pada tahap ini, kegiatan pembelajaran tentang 
perkembangan teknologi produksi melalui model Group Investigation dilaksanakan sesuai dengan rencana pembelajaran yang telah disiapkan sebelumnya, sebagaimana terdapat pada lampiran 2 pada pertemuan siklus I. Pembelajaran tindakan ini diberikan berdasarkan hasil observasi awal yang dalam hal ini hasil belajar siswa masih sangat rendah. Pelaksanaan siklus I, pertemuan pertama guru dan siswa merencanakan bersama sama materi apa yang diajarkan pada pertemuan kedua. Pada tahap ini peneliti memulai pembelajaran dengan memberitahukan kepada siswa tujuan yang ingin dicapai dalam pembelajaran. Selanjutnya guru menjelaskan materi sesuai dengan tema pembelajaran, kemudian guru menyuruh siswa untuk mempresentasikan hasil materi yang mereka dapatkan dari berbagai sumber yang ada dan membagikan lembar kerja siswa, setelah para siswa berdiskusi guru bertanya kembali tentang materi yang diajarkan apa siswa sudah mengerti atau sebaliknya, selanjutnya pada akhir siklus I, siswa diberi tes akhir ( post tes ) dengan soal sesuai dengan materi yang telah dibelajarkan. Peneliti menentukan hasil belajar siswa melalui 3 penilaian yaitu penilaian secara kognitif, afektif dan psikomotorik sehingga menghasilkan siswa yang tuntas dan tidak tuntas.

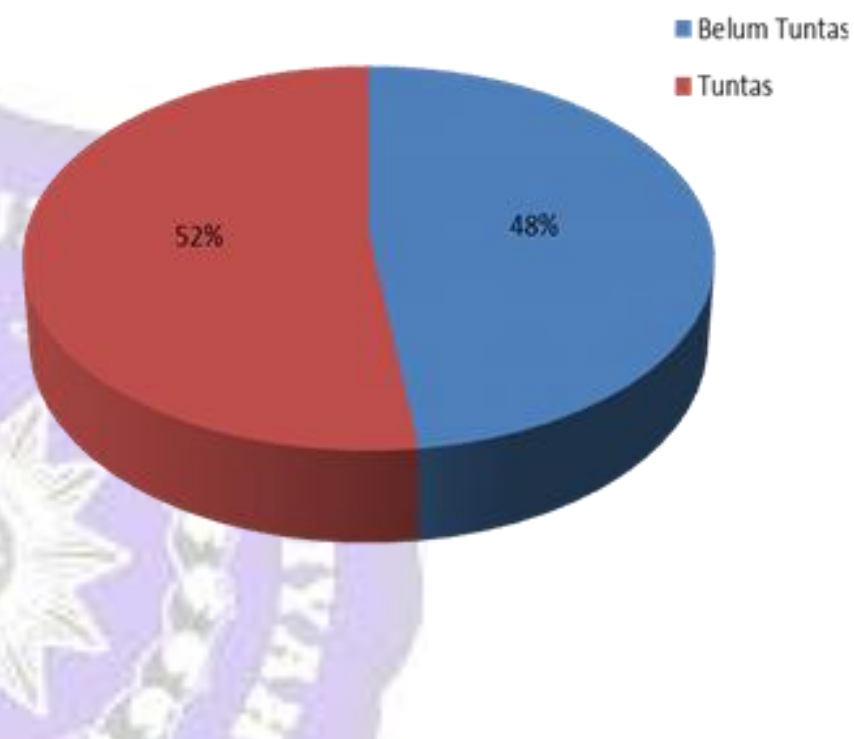

Gambar 1 Hasil Belajar siswa pada Siklus I

Guna mencapai pembelajaran sesuai dengan yang diharapkan, maka kesulitan- kesulitan harus diperbaiki kemudian diterapkan pada pembelajaran selanjutnya. yang perlu dilakukan berkenang dengan upaya perbaikan pada siklus II, yaitu : 1). Peneliti menjelaskan kembali materi tentang perkembangan teknologi produksi, 2). Memberikan moivasi pada siswa agar lebih kosentrasi dalam 
menggikuti pembelajaran, 3). Peneliti lebih banyak membimbing siswa yang mengalami kesulitan dalam mengerjakan tugas baik kelompok maupun individu.

\section{Hasil Pelaksanaan Pembelajaran Siklus} II

- Tahap persiapan. Pada siklus II, peneliti telah melakukan perbaikan terhadap rencana kegiatan pembelajaran berdasarkan hasil analisis pada siklus I. Hal - hal yang perlu diperbaiki pada siklus II yaitu : 1). Guru lebih memperhatikan siswa yang hasil belajarnya masih rendah 2). Lebih mengefektifkan waktu. Pelaksanaan kegiatan pembelajaran sama seperti pada siklus I yaitu dengan memggunakan model Group Investigation. - Tahap Pelaksanaan Tindakan. Tahap pelaksanaan tindakan pada siklus II sama seperti pada pelaksanaan iklus I, namun lebih menitik beratkan pada aspek aspek yang belum dipahami oleh siswa pada siklus I. Kegiatan yang dilakukan pada siklus II yaitu, diawali dengan mempersiapkan siswa mengikuti pembelajaran, menyampaikan tujuan pembelajaran dan kopetensi dasar yang akan dicapai pada akhir proses pembelajaran, memberikan motovasi kepada siswa agar bersemangat dalam belajar, serta melakukan apersepsi (tanya jawab tentang materi yang telah diajarkan). Pada tahap awal peneliti meminta siswa untuk memperhatikan penjelasan guru tentang materi perkembangan teknologi produksi yang diajarkan. Pada langkah selanjutnya siswa diberikan kesempatan untuk menanyakan hal - hal yang kurang di pahami oleh siswa, sehingga siswa mudah dalam memahami materi pembelajaran. Selanjutnya peneliti menyuruh siswa untuk berdiskusi dan bembagikan LKS pada tiap kelompok dan mempresentasikan hasil mereka didepan kelas. Selanjutnya peneliti memberikan evaluasi kepada siswa untuk menguji sejauh mana pemahaman dan hasil belajar siswa tentang materi yang sudah diajarkan oleh peneliti, serta memberikan bimbingan khusus pada siswa yang mengalami kesulitan dalam belajar. Pada tahap akhir pembelajaran, peneliti bersama siswa menyimpulkan materi pembelajaran 
dan memberi penguatan kepada siswa agar selalu mengulang kembali materi yang diajarkan dirumah.

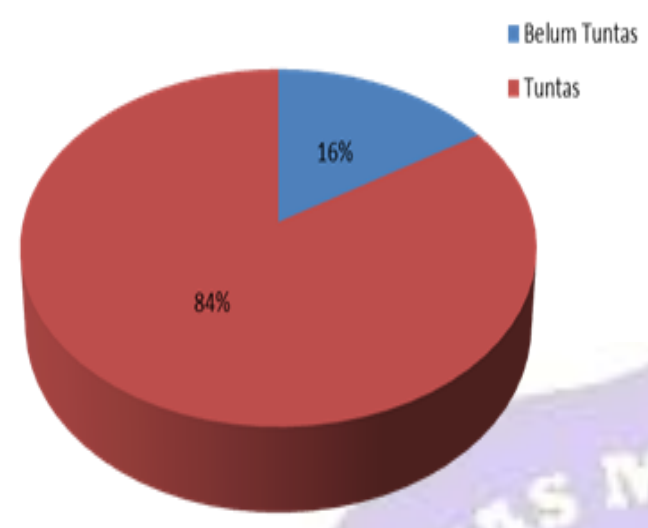

Gambar 2 Data Hasil Belajar Siswa dalam Pembelajaran IPS Siklus II

Pada siklus I masih banyak ditemui kesulitan - kesulitan yang dihadapi siswa. Kesulitan tersebut kemudian diperbaiki pada pembelajaran siklus II. Padapembelajaran siklus II , peneliti berusaha meningkatkan kembali mengenai materi perkembangan teknologi produksi yang belum dipahami dengan mengajukan pertanyaan pertanyaan yang berhubungan dengan materi - materi yang diajarkan. Dari hasil analisis data yang diperoleh nilai rata - rata pada siklus II telah mengalami peningkatan dari siklus $\mathrm{I}$. Nilai rata - rata yang diperoleh siswa pada siklus II adalah 73,6 dengan kategori baik, yang semula pada siklus I hanya 66,8 dengan kategori cukup. Artinya, nilai tersebut telah mencapai indikator yang ditetapkan yaitu sebesar 70. Perilaku siswa pun sudah mengalami perubahan kearah positif. Sebagian besar siswa berkosentrasi dan memperhatikan dengan baik saat guru memberikan penjelasan maupun saat siswa berdiskusi. Dengan demikian perbaikan yang dilakukan pada saat siklus II sangat bermanfaat dan berpengaruh pada hasil belajar siswa. Siswa lebih berkosentrasi pada pelajaran sehingga nilai hasil belajar siswa menjadi lebih baik. Kesulitan kesulitan yang dialami siswa sudah berkurang. Penjelasan dari peneliti juga sudah dapat dipahami dengan baik oleh siswa. Keaktifan siswa dikelas juga meningkat, meskipun masih ditemukan ada beberapa siswa yang kurang aktif, tetapi perilaku siswa sudah lebih baik dari siklus I.

\section{Kajian Penelitian yang Relevan}

Rismawatin （2012 ) pada penelitiannya yang berjudul penerapan 
model pembelajaran kooperatif learning tipe group investigasi (GI) untuk meningkatkan hasil belajar siswa dalam pembelajaran IPA tentang bumi dan alam semesta menjelaskan adanya peningkatan hasil belajar siswa setelah dilakukan pembelajaran dengan nilai rata - rata siklus I yaitu 72,60 dengan presentase siswa mencapai KKM sebanyak $63,72 \%$, siklus II yaitu 78,87 dengan presentase $79,31 \%$ dan siklus III yaitu 83,44 dengan presentase $86,20 \%$, hasil belajar efektif dan pisikomotoriknya dikatagorikan sangat baik karena dari siklus I sampai siklus III mengalami peningkatan dan rata - rata dalam semua aspek mencapai diatas $80 \%$ dan penerapan pembelajaran tipe GI telah berhasil meningkatkan hasil belajar siswa kelas V SDN 2 Suntenjaya lembang tahun ajaran 2011/2012. Penelitian selanjutnya dilakukan oleh Botutihe, 2013 dengan judul meningkatkan hasil belajar siswa IPA pada materi lingkungan sehat melalui model GI siswa kelas III SDN 6 Limboto Kabupaten Gorontalo. Disimpulkan bahwa melalui model tersebut dalam pembelajaran IPA dapat meningkatkan hasil belajar siswa rata - rata pada siklus I dari $53 \%$ menjadi $64,44 \%$, meningkat dan pada siklus II dari 74,00 $\%$ menjadi $80 \%$. Perbedaan dari kedua peneliti diatas adalah teletak pada mata pelajaran yang berbeda sedangkan persamaannya adalah sama - sama menggunakan model pembelajaran kooperatif learning tipe group investigation.

\section{PENUTUP}

\section{Simpulan}

Berdasarkan hasil penelitian dan pembahasan, dapat disimpulkan bahwa : Hasil belajar IPS siswa kelas IV SDN 6 Bulango Selatan Kecamatan Bulango Selatan Kabupaten Bone Bolango setelah dilakukan tindakan melalaui penerapan model Group Investigation mengalami peningkatan yang signifikan. Pada pelaksanaan tindakan siklus । diperoleh data hasil belajar siswa dengan nilai rata - rata yaitu 66,8 dengan nilai terendah 50 dan nilai tertinggi 90, sedangkan ketuntasan belajar siswa secara klasikal mencapai $48 \%$. Pada pelaksanaan tindakan siklus II data yang diperoleh adalah sebagai berikut rata - rata nilai kelas yang dicapai adalah 73,6 dengan nilai terendah 50 dan nilai tertinggi 100 , sedangkan ketuntasan belajar klasikal 
yang dicapai siswa sebesar $84 \%$. Hal ini menunjukan peningkatan nilai rata - rata kelas dari observasi awal, siklus I, dan siklus II.

\section{Saran}

Berdasarkan simpulan penelitian tindakan di kelas IV SDN 6 Bulango Selatan, Kecamatan Bulango Selatan, Kabupaten Bone Bolango, ada berapa saran peneliti, yaitu : 1). Dalam Pembelajaran IPS guru harus lebih kreatif dalam menggunakan model model pembelajaran agar suasana kelas lebih kondusif, efektif dan menyenangkan sehingga mata pelajaran IPS tidak lagi dianggap sebagai mata pelajaran yang sulit dan membosankan; 2). Pembelajaran kooperatif model group investigation dapat diterapkan pada konsep lain dan mata pelajaran lain tetapi dengan perbaikan - perbaikan dalam proses pembelajaran yaitu motivasi guru agar siswa lebih berperan aktif dalam situasi kelompok maupun diskusi kelas, sehingga diharapkan hasil belajar siswa lebih optimal.

\section{DAFTAR PUSTAKA}

Maufur, hasan F. 2009. Sejuta jurus mengajar mengasyikan. Semarang : Sindur Press.

Rusman.2011.model-model pembelajaran, mengembangkan profesinalisme guru. Jakarta : Rajawali Pers.

Suprijono, Agus. 2009. Cooperative Learning - Teori dan Aplikasi PAIKEM.. Yogyakarta : Pustaka Pelajar.

Wiriaatmadja, Rochiati. 2009. Metode Penelitian tindakan kelas. Bandung : PT Remaja Rosdakarya. 